\title{
A next generation of conditional cash transfer programs
}

\author{
Marcelo Neri \\ Fundação Getulio Vargas / FGV Social-Centro de Políticas Sociais and \\ Escola de Pós-Graduação em Economia da Fundação Getulio Vargas \\ Rio de Janeiro / RJ — Brazil
}

\begin{abstract}
This article evaluates the role of the Brazilian federal Conditional Cash Transfer programs (CCTs) such as Bolsa Familia and Bolsa Escola during the past recent years and discusses their future. Based on previous empirical evidence based on my own work, I propose an integrated framework with two complementary perspectives. The first perspective is a goal approach based on the short term aggregated influences exerted by these programs, organized under four headings, namely: equality, prosperity, stability and sensibility. The emphasis here is to compare the results of Bolsa Familia with other official programs such as BPC and Social Security benefits. The second perspective follows a means approach inspecting the microeconomic mechanisms through which CCTs operate, comparing the impacts on CCTs beneficiaries versus non-beneficiaries. Such perspective helps in dialoguing about the relevance of different CCTs attributes, and to discuss possible desirable upgrades.
\end{abstract}

Keywords: income policies; poverty; conditional cash transfers.

\section{Uma próxima geração de programas de transferência de renda condicionada}

Este artigo avalia o papel de programas de transferência de renda condicionada (sigla CCTs em inglês) como o Bolsa Família e o Bolsa Escola federais, sua expansão recente e discute o seu futuro. Organizamos evidências empíricas de trabalhos nossos anteriores, proponho um arcabouço integrado a partir de duas perspectivas complementares. A primeira utiliza abordagem-fim via influências agregadas de curto prazo exercidas por esses programas através de quatro componentes: equidade, prosperidade, estabilidade e sensibilidade. A ênfase é sobre a comparação dos resultados do Bolsa Família com outros programas como o Benefício de Prestação Continuada (BPC) e a Previdência Social. A segunda perspectiva segue abordagem-meio inspecionando os mecanismos microeconômicos pelos quais os CCTs operam, comparando os impactos sobre os indivíduos beneficiários destes programas vis-à-vis aqueles que não o são. Essa segunda perspectiva ajuda no diálogo sobre a relevância dos diferentes atributos dos CCTs e a discutir possíveis melhorias.

Palavras-chave: políticas de renda; pobreza, programas de transferência de renda condicionada.

\section{Una próxima generación de programas de transferencia condicionada de ingreso}

Este artículo examina el papel de las políticas de transferencias condicionadas de ingreso (CCT’s en Inglés) como Bolsa Familia y Bolsa Escuela, su reciente expansión y su futuro. Organizamos la evidencia empírica de nuestros trabajos, propongo un marco integrado desde dos perspectivas complementarias. La primera utiliza un enfoquefinal desde una gama de influencias macroeconómicas a corto plazo ejercidas por esos programas a través de cuatro componentes: equidad, prosperidad, estabilidad y sensibilidad. El énfasis es en la comparación de los resultados del Bolsa Familia con otros programas, como las prestaciones de la Seguridad Social y BPC. La segunda utiliza un enfoque-medio a través de la inspección de los mecanismos por los que las CCT’s operan mediante la comparación de los impactos sobre los beneficiarios vis-à-vis aquellos que no son. Esto ayuda en el diálogo sobre la relevancia de los diferentes atributos de las CCT's y posibles mejoras.

Palabras clave: políticas de ingresos; pobreza; programas de transferencias condicionadas de ingresos. 


\section{INTRODUCTION}

Income inequality and poverty decreased in Brazil and in most of Latin America countries since the beginning of the new millennium, when Conditional Cash Transfer programs (CCTs) became widespread throughout the continent. Yet, what exactly was the contribution of CCTs for this outcome? Considering the slowdown of growth and the lack of fiscal space, is the CCTs agenda over? This article evaluates the role played by Brazilian CCTs at the federal level such as Bolsa Família and Bolsa Escola during the recent years and discusses their future.

This article uses previous empirical evidence and policy changes resulting from the author's work in the field, and proposes an integrated framework with two complementary perspectives. The first perspective is a goal-approach based on the short run macroeconomic influences exerted by these programs, organized under four headings, namely: equality, prosperity, stability and sensibility. This approach is useful to evaluate the overall past performance of the programs, including impacts on a vast array of social welfare measures. These involve measures based on per capita income, such as poverty and inequality, and also on aggregate output and its short term multiplier effects. Moreover, it is possible to assess the instability associated with the electoral cycle and changes to people's perceptions, including overall life satisfaction, and different groups' attitudes towards the program. The emphasis here will be to compare the results of Bolsa Família with other official programs such as the Continuous Cash Benefit (BPC) and Social Security benefits.

The second perspective follows a means-approach inspecting the mechanisms through which CCTs operate. In this part, the results of empirical exercises will be used to compare observed changes on CCTs beneficiaries versus non-beneficiaries. It is useful to consult the details of previous work on CCTs and to discuss desirable upgrades. Another fourfold taxonomy is proposed including: a) the impacts on the current family budget constraint through its payment system; $b$ ) the direct welfare effects of giving priority to low-income beneficiaries in the provision of public services and other merit goods (such as sewage and health services); c) augmenting individual production function through different conditionalities on basic education and by productive inclusion initiatives such as professional education; and d) launching a new agenda aimed to provide better access to markets to the poor and/or improving their ability to smooth adverse shocks through savings, credit and insurance instruments, as well as financial education and consumer protection.

After the introduction, the first two sections discuss CCTs results and transmission mechanisms. The fourth and last section discusses the desirable features of a next generation of CCTs programs, such as a Bolsa Família 2.0 (or a Bolsa Escola 3.0). In this section, the article discusses innovation in payment systems and the design of conditionalities such as the use of multidimensional poverty index in the selection of beneficiaries and the amount of cash transferred, as well as the role played by mothers in the transmission channels of the program. The article also emphasizes the connection between CCTs and the content of the international social agenda (e.g. the United Nations Sustainable Development Goals), as well as it discusses the role played by CCTs in order to integrate various sectoral policies targeted at the poor population, implemented at different government levels. 


\section{RESULTS}

GDP is often used as a synthesis of economic success. However, in order to measure the progress of nations, other dimensions of human experience must be analyzed. A good script is found in the book "(Mis)Measuring Our Lives", by Stiglitz, Sen and Fitoussi (2010). The book brings the conclusions of a committee of notables on how to measure the progress of nations in four areas: prosperity, equality, sensitivity and sustainability. In this article a comparative perspective is used to measure the aggregate and short-term impacts inflicted by different Brazilian income policies on these four elements with microdata from public use household surveys.

a. Equality effects - The impact of CCTs on Brazilian income inequality has been widely documented in the literature. Kakwani, Neri and Son (2010) calculate the degree of targeting of different social transfers using a Social Welfare Function particularly sensitive to the lower tail. This article follows the same path and calculates the impact on the Gini coefficient, the mostly widely used measure of inequality, for each Real spent. Bolsa Família is by far the most efficiently targeted program with values of the targeting indicator greater than 3 between 2001 and 2012, reaching 3.12 in 2012. The targeting indicator for the labor income is around 1, reaching 0.97 in 2012, which means that a transfer of one Real from Bolsa Família will increase the social welfare by about 3.22 times than that of one Real earned from the labor market. The value of the targeting indicator for the BPC and Social Security benefits in 2012 was 2.18 and 1.01, respectively. BPC is also efficient in targeting lower income families, but its degree of impact is much smaller than Bolsa Familia's. Social security, which has a large component of public subsidy, is not as well targeted. At this point it is worth disentangling the impacts of social security benefits up to one minimum wage and values above, once the former had an impact 88.6\% greater between 2001 and 2012. Since 1998 the Brazilian government has been giving higher adjustments to social security benefits on the Constitutional floor of one minimum wage.

b. Prosperity multiplier - Government transfers to individuals and families play a central role in the Brazilian social protection system, accounting for almost 14 percent of GDP in 2009. While their fiscal and redistributive impacts have been widely studied, the macroeconomic effects of transfers are harder to ascertain. Neri, Vaz and Souza (2013) constructed a Social Accounting Matrix (SAM) for 2009 and estimated short-term multipliers for seven different government monetary transfers. If the government increased Bolsa Familia expenditures by 1 percent of GDP, overall economic activity would grow by 1.78 percent, the highest effect. The Continuous Cash Benefit (BPC) comes in second place with 1.19. Unemployment insurance and subsidies for low paid formal workers - such as Abono Salarial and Salário Família - achieve the same target and share a multiplier of 1.06. Three transfers - the private-sector pension (0.53), public servants' pensions (0.52) and FGTS withdrawals (0.39) - had multipliers lower than 1 . The multipliers for other relevant macroeconomic aggregates household and total consumption, disposable income etc. - reveal a similar pattern. Thus, under the stringent assumptions of this model, the results do not allow to reject the hypothesis that government transfers targeting poor households, such as Bolsa Familia, help foster economic expansion. Naturally, it should be stressed that the multipliers relate marginal injections into government transfers to short-term economic performance, either real growth or inflation if there is no idle capacity, which is also useful to analyze. In the long term, there is no doubt that what truly matters is the growth of the country's productive capacity. 
c. Happiness - Deaton (2013) has shown, using the 2006 Gallup World Poll microdata, that there is a positive long-term correlation between life satisfaction and material conditions, throughout the world, if we include the poorest countries in the analysis. However, Neri (2014) using the same survey has shown that Brazilian happiness is relatively indifferent to material conditions, which is exemplified by the fact that no country in the world, among the 132 surveyed, shows a lower correlation between the two variables than Brazil. A good deal of the relation between income and happiness in Brazil is explained by the transition of those with no income at all to the lowest income range studied, indicating a great potential for public policies focused on the poorest population. This article illustrates with Brazilian data that the relation controlled by several socioeconomic factors between implicit income variation and the variation of happiness of the same person over time shows positive results when compared to other income transfers, less targeted to the poorest population. Beneficiaries of the Bolsa Família program earn an additional $29.9 \%$ points for happiness in relation to non-beneficiaries while this effect is much lower for other transfers such as social security benefits (14.4\%) and unemployment insurance (11.8\%). This result indicates that redistributive policies, of which Bolsa Família is the best targeted Brazilian example, can lead, in aggregate terms, to greater overall happiness of the nation, at least in the short term.

d. Electoral cycles instability - The literature on electoral cycles describes the behavior of politicians who embellish their success in election years as a way to influence the result of the elections. According to the political economy literature, the outcome of elections is determined by the median voter - hence, the option here for the use of median income, which is dated close to the first round of the elections, at the beginning of October, when the PNAD questionnaire is usually launched. PNAD did not collect data in 1994 and 2010, so it is not possible to capture the full effects of cycles associated with the two episodes. Out of eight elections, in the electoral years there were eight median real income increases while in the post electoral years there were seven losses. Using the 1981 to 2013 period, in the electoral years, the average net income gain was of $11.33 \%$ while in the years after the electoral years, the average median income fell $-7.3 \%$. Similar qualitative results are found for poverty statistics.

Neri (2009) inspects the mechanism that connects elections and changes in the Brazilian social context from 1992 to 2006 using income equations for different income sources. Income increases were greater in election years, characterizing the electoral cycle. In those years, on average, income from social programs increased the most (22.57\%), followed by social security (10.51\%) and labor earnings (3.16\%). Finally, despite that per capita household income smoothes the effects examined here, the income of people of voting age increases more in an election year than the income of children and teenagers who do not participate directly in political contests. In this case, the main relative gain comes from social programs: during election years this income grows $3.43 \%$ more for eligible voters than children and teenagers below the voting age. Social security follows this trend with a relative increase of $2.74 \%$ for eligible voters, followed by the indirect effect of employment income with $1.27 \%$. These numbers indicate that the extension of income transfer programs is tied to the election cycle. This creates a main objection in terms of political opportunism to the Conditioned Cash Transfer programs ${ }^{1}$.

\footnotetext{
${ }^{1}$ Longitudinal data collected just before and after the July 2013 street demonstrations in Brazil have shown that even with Bolsa Familia social justice aim and relatively low fiscal cost, being against the program was among the eight main explanatory variables for participation in the protests.
} 
e. In summary - Overall, using the ends approach during the period of falling inequality in Brazil, it is possible to see that CCTs were by far the best target program compared to other official cash transfers. Given the urgent need for fiscal adjustment and the imperative to preserve the poorest population from its social costs, CCTs tend to be working more on the solution than on the problem. The high progressivity of CCTs leads to two additional results. First, much higher demand multipliers on GDP, given higher consumption expenditures propensities of low income individuals. Second, a higher impact on subjective measures of life satisfaction, given the higher sensibility of the poor with respect to cash transfers. On the down side, income transfers are used opportunistically in parallel with the electoral cycle in Brazil, which is undesirable from a normative sense and generates unnecessary instability. This side effect should be dealt with in Brazilian income policies reform, including CCTs.

\section{IMPACT CHANNELS}

\section{A. TRANSMISSION CHANNELS}

Before examining specific examples showing the effects of the transmission mechanisms of the Bolsa Familia Program (PBF) on the lives of its beneficiaries, it is interesting to put in perspective the program's various transmission mechanisms. The PBF has several channels for overcoming poverty. The most direct channel, shown on the left-hand side of figure 1, represents the transfers and taxes that affect people's current net income after the impact of other channels that affect the determination of gross income in the factor market, particularly the labor market. The PBF privileges women in 93\% of the cases as direct recipients of monetary income, also offering financial education and financial services. Another aspect emphasized in the diagram is the PBF as a conditional income transfer program that seeks to influence the education and health of its beneficiaries, increasing their demand through conditionalities.

The right-hand side of figure 1 shows the policies that affect the provision of public goods and services whose use directly affect people's welfare. At the top are the policies that prioritize the provision of education and health services to PBF beneficiaries, such as the prioritization of poorer children's access to day care centers, or the greater transfer of educational resources to schools with more than half of their students benefiting from the PBF. The granting of differentiated subsidies to Bolsa Família beneficiaries in the access to technical courses or in terms of urban mobility (providing low cost public transportation or free transportation for students) holds the potential to benefit the supply of health and education policies. This kind of policies can bring the lowest income population not only closer to the government but also to the market, which becomes a fundamental axis given the current scarce fiscal space.

It is interesting to see the direct impact of the program on the place of consumption (whether inside or outside homes) through the supply of goods and public services. The provision of public services such as sewage and telecommunications, for example, are part of the last possibility of policies still to be focused on the poorest population. The dynamic of housing financing is an example of the potential use of PBF and the Single Social Registry (CadÚnico) in order to provide financial subsidies to the poorest population for accessing merit goods. 


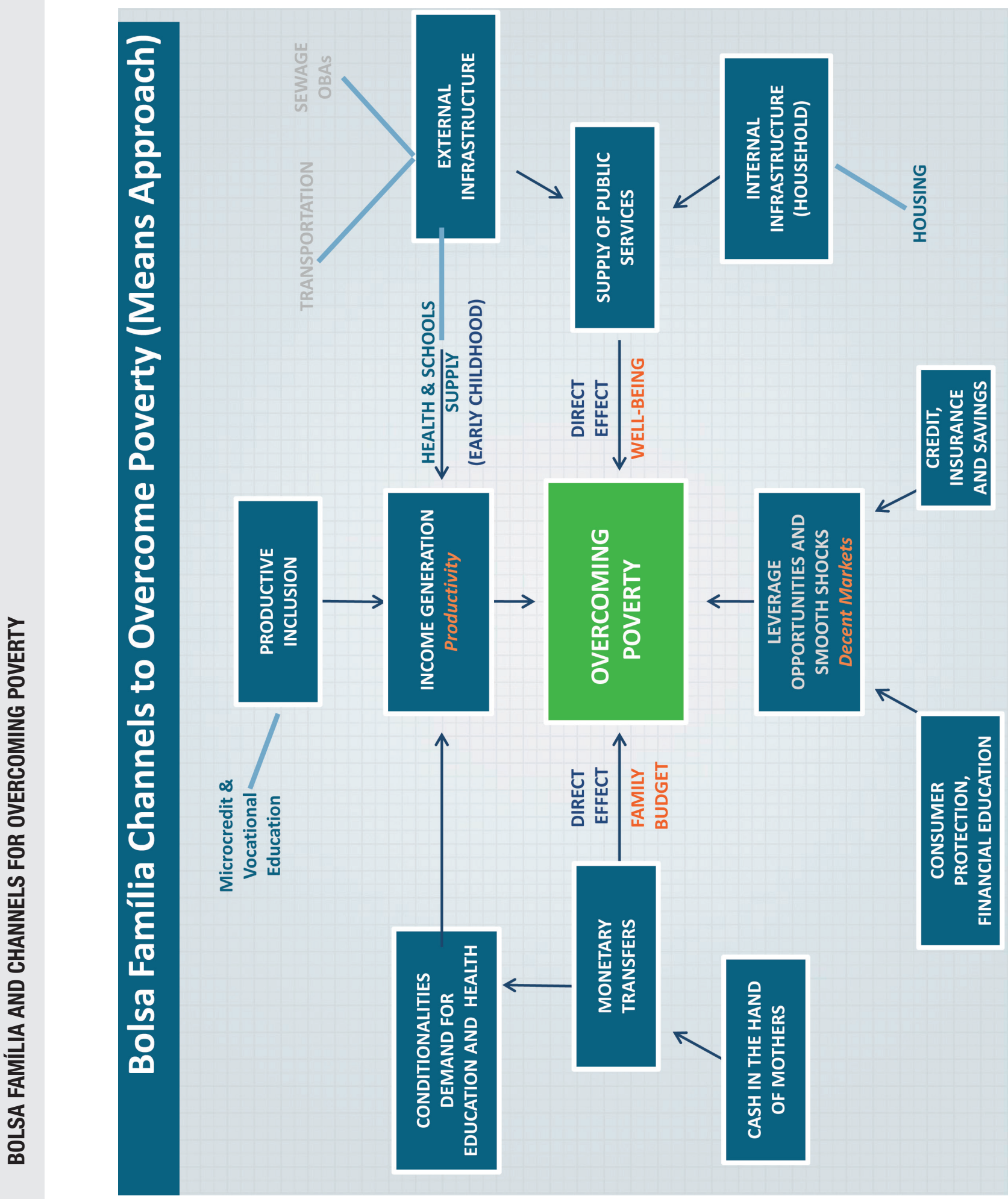


The effect on the right side of the figure goes directly to the welfare of the people, while on the left side, represented by the constant monetary transfer, the channel of impact is related to the budget constraint. To have a structural view of the observed change process, it is necessary to go deeper into the budget constraint and think about the income generation of families over different periods of time, as exemplified in the upper part of the diagram. This part of the diagram refers to actions that affect wage and entrepreneurship, such as the impact on the demand of the Food Acquisition Program (PAA), or on the informality, such as the Individual Micro-Entrepreneur (MEI). This part also includes the change in stocks of assets and resources of families, which implies a longer term effect, where the emphasis is on regular or professional education, using CadÚnico as a targeting and operational tool.

Finally, the lower part of the diagram represents the last part of the approach proposed here. It is necessary not only to take the poor population to the market but also to take the market to serve this population. The poor population deserves quality public services offered or regulated by the government, as well as has to be treated as the protagonist of their own lives. If well regulated, credit consigned to social benefits goes along this line, leveraging welfare gains. This is the case especially for public policy in microfinance, such as microcredit and microinsurance. Notwithstanding, the emphasis of this text falls on simpler elements such as access to bank accounts and the possibility of deciding for deposit and savings.

\section{B. CURRENT BUDGET CONSTRAINT: FOOD SUBSIDIES VERSUS CASH TRANSFERS}

The first effect given by CCTs directly impacts the family budget through transfers and taxes in addition to incomes earned in the factors markets. It is important to emphasize here tax exemption and public transfers such as CCTs. The Family Budget Survey (POF) implemented by the IBGE in 2002-03 and 2008-09 allows assessing the effects of the experience of ICMS (State level tax on circulation of goods and services) reduction in some of the Brazilian states comparing them to others states that were not included in the experience. The expansion of Bolsa Familia since 2004 also allows to compare the impacts on the eligible families for income transfer of the program with the ineligible families. The POF, on the other hand, allows a comparative view of the effects. In general, the exemption-effect reduces monetary expenses on food and perceived expenses, while Bolsa Familia-effect reduces non-monetary expenses on food. The effects of the tax exemption are perceived more broadly on the population while Bolsa Família reduces the perception of food insecurity only among the poor population. Maybe that is why the program presents greater capacity to increase body mass of its beneficiaries, which was not observed in the tax exemption experiences. Each policy has an effect on different variables and groups of people, suggesting complementarity of instruments.

\section{CONDITIONALITIES AND TIME IN SCHOOL}

Besides the direct income effect, CCTs also attempt to influence the likelihood of exiting poverty in the long-term through education conditionalities. Neri and Osorio (2016) study conditionalities 
effects of Brazilian CCTs on time in school and its components (enrollment, attendance and school journey) using PNADs special supplements about basic education applied in 2004 and 2006. An increase of $67 \%$ in the population covered by PBF in this period was followed by a marked change in the mean and the equality of the indicator 'time in school' and its components. This empirical setting allowed testing dosage-effects of the program. Initially, they register the rise in the mean and in the equality of the indicator 'time in school' and its components. The first identifying hypothesis is related to the economic situation of families with children aged between six and 15, eligible for the educational benefit of the program if the monthly household income per capita is less than $\mathrm{R} \$$ 100, discounting any official transfers. The income eligible group aged between 6 and 15 years, compared to the ineligibles, after the expansion of PBF, has a $9 \%$ higher chance to enroll, $22 \%$ higher to meet attendance conditionality and $5 \%$ lower to study only 4 hours/day. This result suggests that PBF eligible population were benefited with an increase in the time in school. Next, the analysis was restricted to just the income of the eligible population to incorporate the impacts cumulative margin set by the age eligibility criterion. The second hypothesis is related to the discontinuity of the maximum age criterion to receive the benefit. We cannot reject the hypothesis of causal impact of "Bolsa Familia". Next, the analysis was restricted to just the income of the eligible population to incorporate the impacts cumulative margin set by the age eligibility criterion. We compared teenagers who turned 16 years old less than two months after December 31 with teenagers that turned 16 in the last two months of the previous year, thus no longer eligible for the program after December 31st. After PBF expansion, the age eligible group were $62 \%$ more likely to go to school, $8 \%$ more likely to meet with the attendance conditionality and 5\% more likely to study more than 4 hours/day. Finally, tests on motivation alleged by the students to transgress attendance and evasion conditionalities limits do not allow the discard of income relief effects related to the program.

\section{ACCESS TO FINANCIAL MARKETS}

Stability and equality have marked effects on the level of individual and societal welfare and should be studied in an integrated manner. In general, the dispersion of individual welfare measures, such as income or per capita consumption, can be analyzed from two perspectives: the inequality of mean living standards and the observed fluctuation in the standard of living of the same person across its own mean between different moments of time. The issue of income volatility has implications for the analysis of programs such as Bolsa Familia. In an analogy with frictional unemployment, if there are always people coming in and out of poverty, the zero poverty rate is as unattainable as zero unemployment. In the new UN Sustainable Development Goals (SDGs), the first goal is of "zeroing" extreme poverty by 2030 , but the aim is in fact to reduce extreme poverty to a rate of less than 3\% of the population. On the other hand, Bolsa Familia contributes to the greater stability of family income. It should be remembered that for those who are closer to the extreme poverty line, losses are much worse than gains of the same amount, making it important to soften consumption instability. In one way or another, the stability effect must be incorporated into the welfare analysis, but for this to happen the supply and demand for financial instruments and the associated motivations must be observed. 
Neri (2014b) shows that the fact that an individual is a beneficiary of the Bolsa Familia program (PBF) increases his/her chances of accessing financial services by $23 \%$. This effect reveals the impact of basic rules of the program, in which beneficiaries are all registered in the Federal Government's Single Social Register (CadÚnico) and receive their benefits from the national bank Caixa Econômica Federal. The operation of the benefits from the bank offers the beneficiary, consequently, greater access to other financial services. In this sense, Bolsa Familia is more than a gateway out of poverty, it is an entry gateway to more sophisticated segments of the financial market, such as credit and insurance. It is possible to advance, designing policies that intentionally use the platform of the program to guarantee access to more and better financial services for the low-income population. In this direction, in May 2016 the Minister for Social Development (MDS) adopted a program that transformed Bolsa Família into a savings account with a debit card.

\section{E. SUPPLY SIDE: DIRECT EFFECTS ON WELL-BEING}

Neri and Andrade (2011) focus on the possibilities offered by Bolsa Família, whether to test the impact of income on access to services, or as a platform for granting subsidies. The marked expansion of the program between 2004 and 2006 served initially as an experiment on how the income increase associated with policies to combat poverty impacts on the coverage of public services. The authors analyzed how much the income increase of this population is related to the increase of their access to public services. The Difference-in-Difference exercise shows that income gains produced an improvement in all public services analyzed (electricity, water, cell phone, internet) except sewerage, which was the only service that did not grow in the period. The higher income provided by the Bolsa Família program did not affect the access to sewerage of the population eligible for the program.

If the Bolsa Familia program itself is not a sufficient condition to lead to the provision of sanitation to the poor population, the data base formed by CadÚnico is an asset that positions the program as a platform through which it is possible to access the poor population. The CadÚnico has the people's location and addresses, which are associated to the program's payment card and allows infrastructure programs to connect with the poorest. In this way, companies can receive incentives or direct subsidy in order to expand their service network focused on the poor population. In particular, the association of Output Based Aid (OBA) incentive schemes with Bolsa Família is a privileged way to provide incentives for public services to reach the poor population.

\section{F. IN SUMMARY}

This section discussed the main channels of impacts of CCTs, which is closer to the debate of possible upgrades than the impact of outcomes discussed in the second section. The section began with a broad conceptual scheme including four channels, moving then to specific examples of each channel. Transfers and taxes that affect people's current net income were discussed, as well as other channels that affect the determination of gross income in the labor market. Then, a discussion was presented on how to influence people's ability to smooth their purchasing power 
instability over time through assets, credit and insurance. Finally, the section presented the role of policies that affect the provision of public goods and services that directly influence people's well-being.

\section{CONCLUSION: THE NEXT GENERATION OF CCTS}

\section{A. NEW SOCIAL FEDERALISM}

One of the central issues of the 1988 Brazilian Constitution was the separation of responsibilities for social policies among the federal entities. In 2000, the creation of the Fund for Poverty Eradication aimed to finance programs implemented in poor regions, such as the federal Bolsa Escola program. This was a second stage in order to organize how the country would address the social policy. However, the decisions about the funds were still centered in Brasília. In 2011, the Bolsa Família program mobilized states to complement the federal social policy with decentralized actions taken by sub-national Governments built on the national Bolsa Família platform. This marked the creation, in a third stage, of the new social federalism.

Brazil has a tradition of imposing national laws and programs without first testing them locally. As a result, more mistakes are made than should be on a national scale and little is learnt from the process. When there is a first test locally and regions can apply the policy in different ways, the likelihood for learning from practice is higher, because this allows comparing results with other localities and verifying whether the innovation has made a difference. For example, Card and Krueger (1994) had the opportunity to learn valuable lessons researching the state of New Jersey in comparison to the neighboring Pennsylvania when the former raised its wage floor in the 1990s. The centralist tradition in Brazil ends up harming the learning process.

As in the Brazilian experience of the state wage floor, started in 2000 in Rio de Janeiro, Rio Grande do Sul, São Paulo, Paraná and Santa Catarina, there is a bias towards richer states entering new social federalism. In the case of the state wage floor, the adhesion of the rich is part of the strategy of delegating powers to optimize wage floors, due to the greater availability of a private sector able to afford them.

On the other hand, fighting poverty must focus on the poor population, through greater contributions of federal resources to those localities with lower mean incomes. Additional leveraging of resources conditioned on effectively overcoming poverty should also be encouraged. The Output Based Aid (OBA) scheme remunerates a posteriori the attainment of comparative advantages in poor areas, which means the improvement of their indicators to a desired level. The state is key to build-up resources and gains of scale in the implementation of complementary strategies for Bolsa Familia, which until now reflected only the federal/municipal relation.

\section{B. LESSONS FROM LOCAL EXPERIENCES}

The city and the state of Rio de Janeiro have created programs named Renda Melhor (RM) and Familia Carioca (FC) respectively. These programs case studies can generate relevant reflections in terms 
of Bolsa Familia upgrades. Both make use of the operational structure of the PBF, which facilitates obtaining information, locating beneficiaries, issuing cards, synchronizing payment dates and access passwords.

The payment system of the two programs complements the estimated permanent per capita income of people under the established poverty line, giving more to those who have less. Similar complement was subsequently adopted in the Brasil Sem Miséria (BSM) federal program and in the Chilean Ingreso Ético Familiar, which also follow the principle of estimation of income used initially in the FC and subsequently in the RM. Instead of using the declared income, the value of Rio's monetary transfers are set using the extensive collection of information obtained from CadÚnico: physical configuration of housing, access to public services, education and work conditions for all family members, presence of vulnerable groups, disabilities, pregnant or lactating women, children and benefits from official transfers such as the PBF. With this multitude of assets and limitations, the permanent income of each individual is estimated. The basic benefit is defined by the poverty gap and priority is given to the poorest.

The programs use international benchmarks as a neutral ground between different government levels and mandates. The established poverty line is the highest used by the first of the United Nations (UN) Millennium Goals: US\$ 2 per person per day adjusted for the cost of living. The other poverty line adopted generally by the UN, US\$1.25, was implicitly adopted when Brazil set as the national extreme poverty line in 2011 the amount of $\mathrm{R} \$ 70$ per person per month. The exchange of methodologies between federal entities has happened both ways.

FC system of impact evaluation also follows students included in CadÚnico but not in PBF as a control group. This is possible because all students in the municipal school system take standardized examinations bi-monthly. In the educational conditionalities, the two programs reward students' progress, a potential advantage for those who most need to advance. The municipal program requires greater school attendance than that of PBF and the presence of students' parents at bi-monthly meetings. Students must achieve a grade of 8 or improve at least $20 \%$ in each exam to receive a bi-monthly premium of $\mathrm{R} \$ 50$. There is no limit to the amount of premiums received per family and the requirements vary in vulnerable areas of the city such as favelas. In early childhood attendance, priority is given to the poor children in CadÚnico to enroll in kindergarten, preschools and complementary activities.

The state program has a payment system inspired on the municipal system. Moreover, the state innovates, transferring the awards given to high school students directly to savings accounts. The prize increases and is paid to the student, who can withdraw up to $30 \%$ annually. The total can reach $\mathrm{R} \$ 3,800$ per low-income student. There are also prizes aimed at young students, in line with Poupança-escola of Brasília and Minas Gerais. The Rio de Janeiro State program rewards according to the performance in the National High School Exam (Enem). Its advancement is to improve independent evaluation on teaching quality, not just graduating or completing high school. The use of external instruments avoids stressing the already tense relationship between school and teachers, and between these and students. 
The State and the city reward education professionals, such as teachers, according to student performance, completing the chain of demand incentives on poor students and their parents. Increased performance is higher among beneficiaries and the presence of their guardians at meetings is twice as high compared to non-beneficiaries.

These results are stronger than a number of recent assessments of randomized experiments in the US, in particular those of Roland Fryer, from Harvard, which have shown little impact of performance awards on student grades. The exception is Fryer (2012), with better empirical results. The new element tested by him is the alignment of incentives given to teachers, parents and students, as Rio de Janeiro city does, more by merit of the Education Department than by the Familia Carioca program, which just completed the line of incentives.

In general, the idea is to explore complementary policies that work strategically in order to leverage the results. The objective is to stimulate, through targets and incentives, synergies between social actors (teachers, parents, students), between areas (education, assistance, work) and different levels of government. The cited programs sum their efforts and divide their work to multiply results and make a difference in the lives of the poor population.

\section{DESIRED UPGRADES}

The principles and some of the practices to be pursued by the next generation of CCTs are summarized below. The conditionalities are subject to more specificities, so the focus here is on innovation in the payment systems.

- Substitute reported current income for estimated permanent income based on the Single Social Registry information set. Search those that are poor and not just those who said that were poor. It is a multidimensional indicator with a rationale for the weights attributed to different components.

- Search for the poorest members of society, and providing in different ways in order to overcome the needs according to each beneficiaries' particularity. . The amount to be granted as benefit should be based on how much the individual needs to achieve the permanent income that equals the established poverty line. This combination creates a gradual exit out of the program. If education improves due to the programs operation, it affects permanent income closing the income gap and reducing the transfers.

- Use of International References such as poverty lines of the first target of the Sustainable Development Goals (SDGs). Connection with best practices and international commitments (UN targets) provides neutral ground to connect different political mandates across time and different government levels. For example, in the case of Local Complements to Federal Bolsa Família.

- Construct bridges also to other federal policies dedicated to other social strata. For example, to broaden the scope of actions for low formal earnings subsidies, such as Abono Salarial and Salário Família programs, that reach individuals receiving between 1 and 2 minimum 
RAP | A next generation of conditional cash transfer programs

wages. There is also the need to construct smoother transition rules such as those in the US program Earned Income Tax Credit (EITC) or the French Revenu Minimum d'Insertion (RMI). 


\section{REFERENCES}

CARD, David; KRUEGER, Alan B. Minimum Wages and Employment: A case study of the fastfood industry in New Jersey and Pennsylvania. The American Economic Review, v. 84, n. 4, p. 772-793, Sept. 1994.

DEATON, Angus. The great escape: health, wealth and the origins of inequality. Princeton and Oxford: Princeton University Press, 2013.

FRYER, Roland. Aligning student, parent, and teacher incentives: evidence from Houston public schools. NBER Working Paper No. 17752, Jan. 2012.

KAKWANI, Nanak; NERI, Marcelo C.; SON, Hyun. Linkages between pro-poor growth, social programs and the labor market: The recent Brazilian experience. World Development, 2010.

NERI, Marcelo C. Income policies, income distribution, and the distribution of opportunities. In: BRAINARD, Lael; MARTINEZ-DIAZ, Leonardo (Org.). Brazil as an Economic Superpower?: understanding Brazil's changing role in the Global Economy. Washington, DC: Brookings Institution Press, 2009. v. 1, p. 221-226.

NERI, Marcelo C. Sistemas de pagamento subnacionais baseados no Bolsa Família. In: CAMPELLO, Tereza; NERI, Marcelo C. (Org.). Programa Bolsa Família: uma década de inclusão e cidadania. Brasília: Ipea, 2013. v. 1, p. 125-136.
NERI, Marcelo C. A felicidade acompanha a renda? In: NERI, Marcelo C.; SCHIAVINATTO, Fábio (Org.). SIPS 2014: percepções da população sobre políticas públicas. Brasília: Ipea, 2014b. v. 1, p. 285-307.

NERI, Marcelo C. O Programa Bolsa Família e a inclusão financeira. In: CAMPELLO, Tereza; FALCÃO, Thiago; COSTA, Patricia V. da (Org.). O Brasil Sem Miséria. 1. ed. Brasília: Ministério do Desenvolvimento Social e Combate à Fome, 2014. v. 1, p. 727-744.

NERI, Marcelo C.; ANDRADE, Thompson. Cadastro Social Único e incentivos a la universalización de servicios de utilidad pública en Brasil. In: JACOB, Olaf (Org.). Inversión en infraestructura pública y reducción de la pobreza en América Latina. Rio de Janeiro: Konrad-Adenauer-Stiftung, 2011.v. 1, p. 33-44.

NERI, Marcelo C.; OSORIO, Manuel C. Bolsa Família, tempo na escola e motivações estudantis. 2016. Mimeografado.

NERI, Marcelo C.; VAZ, Fabio M.; SOUZA, Pedro H. G. F. Efeitos macroeconômicos do Programa Bolsa Família: uma análise comparativa das transferências sociais. In: CAMPELLO, Tereza; NERI, Marcelo C. (Org.). Programa Bolsa Família: uma década de inclusão e cidadania. Brasília: Ipea, 2013. v. 1, p. 193-206.

STIGLITZ, Joseph E.; SEN, Amartya; FITOUSSI, Jean-Paul. Mismeasuring our lives: why GDP doesn't add up. New York: The New Press, 2010.

\section{Marcelo Neri}

Holds a PhD in Economics, Princeton University. Director of FGV Social/CPS. He was also the secretarygeneral of the CDES), president of Ipea and Minister of Strategic Affairs. He evaluated policies in more than a dozen countries and implemented policies at three government levels in Brazil. Edited 10 books on Microcredit; Social Security; Consumption; New Middle Class; Population Perceptions on Public Policies; Planning Public Policies; Diversity; Rural Poverty; and Bolsa Família. E-mail: Marcelo.neri@fgv.br. 